\title{
Morphometric measurements of newborn blue shark Prionace glauca (Linnaeus, 1758) and characteristics of its potential parturition areas in coastal waters of Montenegro (Southeastern Adriatic)
}

\author{
Ilija ĆETKOVIĆ ${ }^{1,2}$, Ana PEŠIĆ ${ }^{*}$, Aleksandar JOKSIMOVIĆ ${ }^{1}$, Jovana TOMANIĆ ${ }^{1}$ \\ and Stefan RALEVIĆ ${ }^{1,2}$ \\ ${ }^{1}$ Institute of Marine Biology, 85330 Kotor, Montenegro
}

${ }^{2}$ Montenegrin Ecologists Society, Bulevar Sv. Petra Cetinjskog 73, 81000 Podgorica, Montenegro

*Corresponding author, e-mail: pesica@ucg.ac.me

The blue shark belongs to the group of the most widespread pelagic sharks in the world. It inhabits the pelagic zone of almost all warm and temperate seas and oceans. As it is one of the most abundant shark species, it is frequently caught in different types of fishing gear operated in the pelagic zone. This study provides the first data on the reproduction of this species in Montenegrin waters (in the Southeastern Adriatic Sea). Six newborn blue sharks were found during our field excursions. For three of them, detailed morphometric measurements are presented. Alongside the newborns, a gravid female was also recorded. The data was collected in the period from April to October 2017. According to the published literature and the data presented in this paper, species reproduction is likely to be seasonal. A review of the areas where the specimens were recorded was carried out in order to infer if the adult females choose them specifically as their parturition grounds.

Key words: Blue shark, Prionace glauca, Adriatic Sea, reproduction, morphometry

\section{INTRODUCTION}

The blue shark (Prionace glauca) is a pelagic oceanic species, which inhabits temperate and tropical waters worldwide. It has the widest geographic distribution among all large sharks (HAZIN \& LESSA, 2005). In the Atlantic, its distribution range spreads from Newfoundland to Argentina in the west and from Norway to South Africa, including the Mediterranean, in the east (COMPAGNO, 1984). It is the most abundant species of all large sharks in the Adriatic Sea and is more frequently found in its southern regions (JARDAS,
1996). It has a slim body with an expressive blue color on the dorsal side, which turns white on the ventral side, while its pectoral fins are quite long. Blue sharks reach up to 383 centimeters in length, with males growing to a similar size to females (NAKANO \& STEVENS, 2008). The species feeds on small pelagic fish and cephalopods, especially squids. This species is placentally viviparous with a gestation period of 9-12 months. The average number of birthed pups is 35 , each being $35-50 \mathrm{~cm}$ long. The young are born usually in spring and summer (STEVENS, 2009). In the Atlantic, females are considered fully mature 


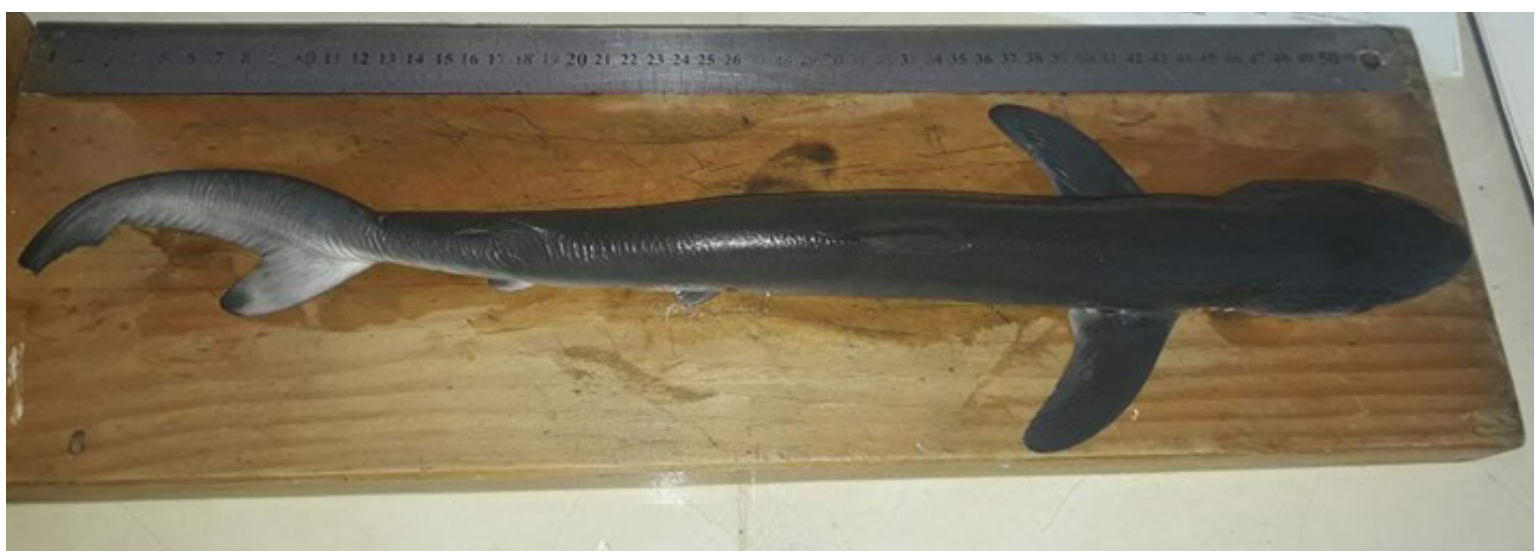

Fig. 1. Dorsal side of the individual caught in Buljarica Cove

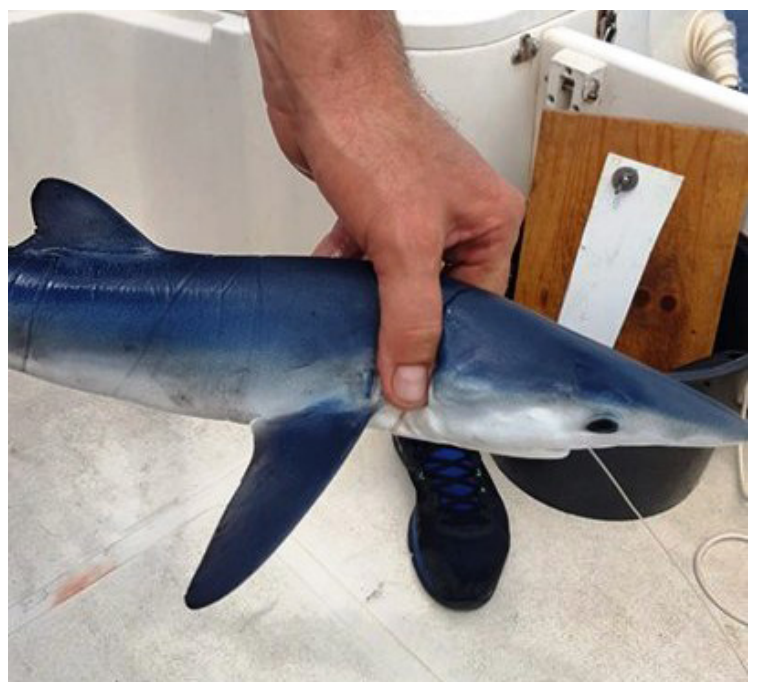

Fig. 2. Fourth newborn individual, caught off Bar

at 221 centimeters in length (PRATT, 1979). In the Mediterranean, gonad observations have shown that females smaller than $120 \mathrm{~cm}$ in total length have immature ovaries, while mature ones were present in specimens larger than $203 \mathrm{~cm}$ in total length (MEGALOFONOU et al., 2009).

Blue sharks are the dominant shark catch for most pelagic longline fisheries operating on the high seas (GILMAN et al., 2009). FERRETTI et al. (2008) showed that, in the Mediterranean, populations of large pelagic sharks, including the blue shark, have declined dramatically during the last two centuries. According to these authors, populations of only 5 of 20 predatory sharks (Sphyrna spp., Prionace glauca, Isurus oxyrinchus, Lamna nasus and Alopias vulpinus) are detected at levels of abundance sufficient for analysis and that these 5 species should be listed as critically endangered (CR) according to IUCN criteria. Currently, blue sharks are considered as critically endangered (CR) in the Mediterranean and near threatened (NT) worldwide by the IUCN. This species is listed in Annex III of Bern Convention (BERN CONVENTION, 1979) and in Annex III of Barcelona Convention (BARCELONA CONVENTION, 1995), which are among the most important documents for the conservation of European wildlife. In Montenegro, the species is not protected by national law and therefore requires the better protection of its population in the coastal waters of this Mediterranean country.

\section{MATERIAL AND METHODS}

The data provided was collected during field excursions within the scope of the conservation project "Reducing the negative impact of tuna fisheries on pelagic sharks and their conservation in the Montenegrin part of the Adriatic Sea". The project was carried out from March to December 2017, within Montenegrin coastal waters. The local fishing community and its members provided a significant contribution of relevant information. All the interviews and field studies were carried out in the company of those fishermen that are fishing in the pelagic zone. Five of them use longlines, three set gillnets and ten carry out big game fishing. They were interviewed and included in the monitoring activities. At each of the locations, where specimens were recorded, the GPS coordinates, the date of 


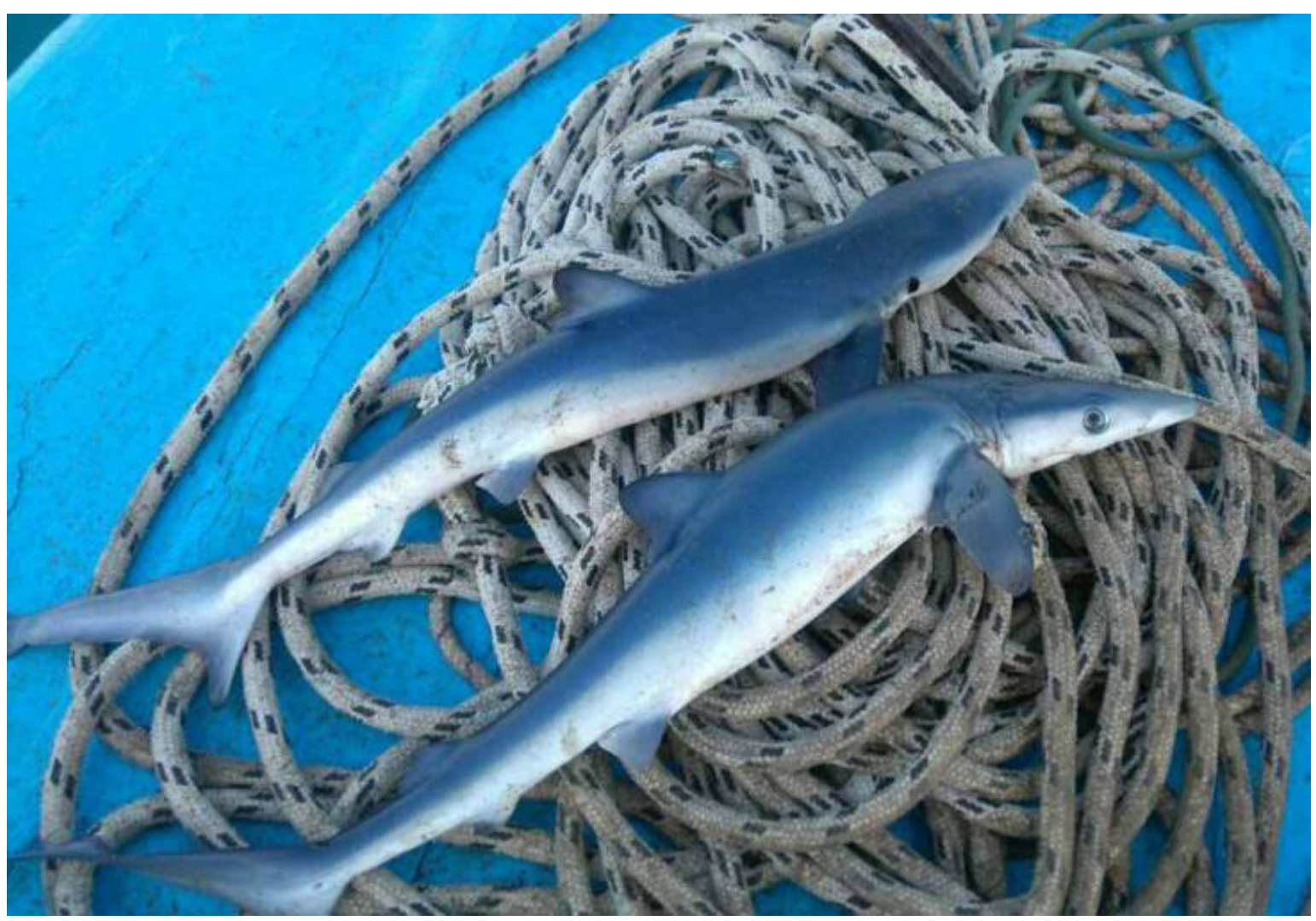

Fig. 3. Two individuals from Trašte Bay

the observation, the depth and the seabed type were noted by interviewing fishermen. For three specimens, of six in total, detailed morphometric measurements were collected. For the other three, no morphometric data is available. This is a result of the lack of information obtained from the fishermen and cases where the specimens were not physically caught, but only recorded using a camera. With the help of the fishermen, we collected the first data on the season and possible parturition grounds of this threatened species within the Montenegrin coastal zone.

\section{RESULTS}

The first recorded newborn was identified on $3^{\text {rd }}$ May 2017. near the coastal town of U1cinj at the Velika plaža beach $\left(41.883404^{\circ} \mathrm{N}\right.$, $\left.19.299212^{\circ} \mathrm{E}\right)$ at an approximate depth of 17 meters. It has been caught with a set gillnet and found dead. The seabed type at the location is sandy. The individual's total length was approximately $50 \mathrm{~cm}$. No additional data exists on this specimen as it was disposed of before a full examination could be carried out. The second newborn was recorded away from shore close to Bar $\left(42.084967^{\circ} \mathrm{N}, 19.031317^{\circ} \mathrm{E}\right)$, during a day in

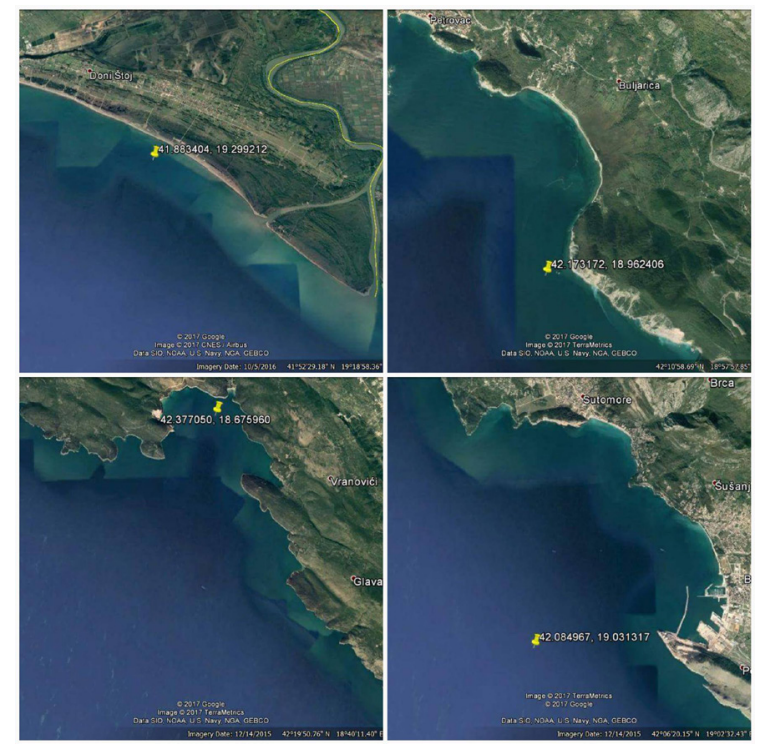

Fig. 4. Scopes of the locations where the blue sharks were found 
the field. It was recorded on the $14^{\text {th }}$ May 2017 , at a depth of 57 meters. The seabed at this location is muddy. The individual was recorded on camera, but was not caught. It was approximately $60 \mathrm{~cm}$ long. It was feeding on sardine chum around the boat. The third individual (Fig.1) was recorded in Buljarica Cove, a coastal village area in the municipality of Budva $\left(42.173172^{\circ} \mathrm{N}\right.$, $\left.18.962406^{\circ} \mathrm{E}\right)$. It was caught in a set gillnet just like the first specimen, at depth of 10 meters on $20^{\text {th }}$ May 2017. The seabed type is sandy here. The individual was found dead in the gillnet, as it was the case with the first one. Its total measured length is $52.9 \mathrm{~cm}$, with a fork length of 44.1 $\mathrm{cm}$. Its weight was $0.401 \mathrm{~kg}$ and it was a male. The fourth newborn (Fig.2) was caught during fieldwork at the same location close to Bar, the same as the second recorded specimen. It was caught on $2^{\text {nd }}$ July2017. while feeding on chum. It was measured and released unharmed. Its total length was $57 \mathrm{~cm}$, its weight was $0.530 \mathrm{~kg}$ and it was a female.

Furthermore, on $7^{\text {th }}$ July 2017, two more newborns were caught (Fig.3) in Trašte Bay $\left(42.377050^{\circ} \mathrm{N}, 18.675960^{\circ} \mathrm{E}\right)$. They were found dead in a gillnet at a depth of approximately 25 $\mathrm{m}$. Their detailed morphometric measurements are given in Table 1. The fisherman informed us that he had caught at least ten small individual blue sharks during June and July at the same location. In addition, we received information from a local fisherman from Budva about a gravid female that was caught and released during big game fishing off Petrovac $\left(42.142183^{\circ} \mathrm{N}\right.$, $\left.18.867325^{\circ} \mathrm{E}\right)$ on $16^{\text {th }}$ May 2017 . The depth at the location was approximately 80 meters. The seabed type is muddy here. According to the fisherman, the female was approximately 2.5 $\mathrm{m}$ in total length and it weighed more than 100 $\mathrm{kg}$. It was recorded on camera and released. The fisherman states that the female started giving birth, as a result of the stress of being caught. The Buljarica Cove, Trašte Bay and Velika plaža areas are very similar in terms of their physical features (Fig.4). The seabed type at all three locations is either muddy or sandy, and can also exist in combination. They are also very close to the open sea, especially Trašte Bay. Not a lot
Table 1. Morphometric measures of the individuals caught in Buljarica (1) and Trašte Bay (2 and 3) taken as described in JARDAS (1996)

\begin{tabular}{|c|c|c|c|}
\hline Measure $(\mathrm{cm})$ & 1 & 2 & 3 \\
\hline Total length (LT) & 52.9 & 65.0 & 69.3 \\
\hline Fork length (FL) & 44.1 & 52.3 & 55.0 \\
\hline Length of snout (POC) & 4.1 & 5.3 & 5.4 \\
\hline Eye diameter $(O)$ & 1.3 & 1.34 & 0.9 \\
\hline Length of pelvic fin (LP) & 7.4 & 9.5 & 9.6 \\
\hline $\begin{array}{l}\text { Length of pelvic fin base } \\
(B P)\end{array}$ & 2.0 & 1.9 & 2.9 \\
\hline $\begin{array}{l}\text { Height of first dorsal fin } \\
\text { (HDI) }\end{array}$ & 2.7 & 3.2 & 3.7 \\
\hline $\begin{array}{l}\text { Length of first dorsal fin } \\
\text { base (BD1) }\end{array}$ & 3.7 & 4.0 & 4.4 \\
\hline $\begin{array}{l}\text { Length of first dorsal fin } \\
\text { (LD1) }\end{array}$ & 5.1 & 5.9 & 6.7 \\
\hline Length of tail holder (PC) & 4.4 & 5.2 & 5.8 \\
\hline Length of tail fin (LPC) & 12.7 & 17.4 & 18.5 \\
\hline Width of mouth (LO) & 3.12 & 3.34 & 3.32 \\
\hline $\begin{array}{l}\text { Space between nasal holes } \\
\text { (IN) }\end{array}$ & 2.0 & 2.0 & 1.87 \\
\hline Length of head (LC) & 12.5 & 14.0 & 15.5 \\
\hline Length of body (LTR) & 17.4 & 20.0 & 21.0 \\
\hline Length of tail ( $L C A)$ & 24.2 & 31.3 & 32.3 \\
\hline SEX & $M$ & $F$ & $M$ \\
\hline Weight & $401.17 \mathrm{~g}$ & $777.76 \mathrm{~g}$ & $829.60 \mathrm{~g}$ \\
\hline
\end{tabular}

of people inhabit the coast surrounding these areas compared to other parts of the Montenegrin coast and they are considered by the locals to be "secluded beaches". The area near Bar is further away from the shore as opposed to other investigated areas, but here, a muddy type of seabed is present.

\section{DISCUSSION}

Blue sharks are estimated to be $55 \mathrm{~cm}$ in total length at birth in the Atlantic Ocean (HENDERSON et al., 2001), while according to STEVENS (2009), they are $35-50 \mathrm{~cm}$ long at birth. The reproduction of this species has a seasonal character, 
with pups being born mostly in spring and summer (PRATT 1979, NAKANO 1994). The individuals found along the Montenegrin coast were all 50$60 \mathrm{~cm}$ long, which suggest that they were born at or near the noted locations. The dates of their captures and sightings occurred in the spring and summer period of the year, which fits well with the previously described data as regards the known birthing season of blue sharks. The report on the gravid female, that started giving birth while being caught, further indicates that the species spawns in Montenegrin waters.

MEGALOFONOU et al. (2005) reported that the blue shark is the most common shark species caught with pelagic longlines aimed at catching tuna and swordfish in the Mediterranean, as noted in the introduction of this article. DAMALAS \& MEGALOFONOU (2012) report the same as a result of their research in the southeastern Mediterranean, where of the 249 large shark specimens that were caught by pelagic longlines, 170 were blue sharks. According to the information gathered from members of the local fishing community, the smallest blue sharks are mostly caught in set gillnets. This impact on newborns is possibly reflected on the whole subpopulation in Montenegrin waters. A large number of the caught blue sharks are juveniles or newborns, so they do not get a chance to produce offspring. BABCOCK (2008) claims that recreational fishing has the potential to cause a significant mortality rate in pelagic shark populations. The blue shark is listed as Critically Endangered in the Mediterranean based on a past decline of up to $90 \%$ over three generations resulting from ongoing overfishing (SIMS et al., 2016). There is a rising concern that the loss of large sharks in the Mediterranean
Sea could cause disturbances in the associated food webs.

DI NATALE (1998) concludes that it is necessary to collect shark bycatch data from large pelagic fisheries, due to the potential consequences of the removal of large shark species from the marine food chains. The available data indicates that the blue shark, as a member of this group, requires better protection in the Adriatic Sea, because of its importance to this ecosystem. As there is a lack of data on this species and pelagic sharks in general, especially within this region of the Mediterranean, it is necessary to conduct further research on and to target conservation efforts towards this globally threatened group of elasmobranchs.

\section{CONCLUSIONS}

Given the above presented data, we suggest that there is relevant evidence to establish the assumption that blue sharks give birth within the Montenegrin coastal zone.

The fact that newborns were recorded in areas of limited human activities, as opposed to other parts of the coast, suggests the possibility that blue shark females are choosing precisely these locations for parturition. Of course, these claims need to be examined in more detail in the future.

\section{ACKNOWLEDGEMENTS}

The authors would like to thank "The Rufford Foundation" for donating the necessary funds to be able to conduct this project and the local fishing community for their irreplaceable contribution to this study.

\section{REFERENCES}

BABCOCK, E. A. 2008. Recreational fishing for pelagic sharks worldwide. Sharks of the open ocean: biology, fisheries and conservation, pp. 193-204.

BARCELONA CONVENTION. 1995. United Nations Environment Programme and Mediterranean Action Plan. Convention for the Protection of the Marine Environment and the Coastal
Region of the Mediterranean, pp. 22.

BERN CONVENTION: Council of Europe. 1979.

Convention on the Conservation of European

Wildlife and Natural Habitats, pp. 10.

COMPAGNO, L. J. 1984. FAO species catalogue,

4. Sharks of the world. An annotated and illustrated catalogue of shark species known to date. FAO Fish. Synopsis, 25: 470-472. 
DAMALAS, D., \& P. MEGALOFONOU. 2012. Occurrences of large sharks in the open waters of the southeastern Mediterranean Sea. Journal of natural history, 46(43-44): 2701-2723.

DI NATALE, A. 1998. By-catch of shark species in surface gear used by the Italian fleet for large pelagic species. Col. Vol. Sci. Pap. ICCAT, 48(3): 138-140.

FERRETTI, F., R. A. MYERS, F. SERENA \& H. K. LOTZE. 2008. Loss of large predatory sharks from the Mediterranean Sea. Conservation Biology, 22(4): 952-964.

GILMAN, E., S. CLARKE, N. BROTHERS, J. ALFAROSHIGUETO, J. MANDELMAN, J. MANGEL, S. PETERSEN, S. PIOVANO, N. THOMSON, P. DALZELL, M. DONOSO, G. MEIDAD \& T. WER. 2008. Shark interactions in pelagic longline fisheries. Marine policy, 32(1): 1-18.

HAZIN, F. H., \& R. LESSA. 2005. Synopsis of biological information available on blue shark, Prionace glauca, from the southwestern Atlantic Ocean. Col. Vol. Sci. Pap. ICCAT, 58(3): 1179-1187.

HENDERSON, A. C., K. FLANNERY \& J. DUNNE. 2001. Observations on the biology and ecology of the blue shark in the North-east Atlantic. Journal of Fish Biology, 58(5): 13471358.

JARDAS, I. 1996. Jadranska ihtiofauna (Ichthyofauna of the Adriatic Sea). Školska knjiga Zagreb, $533 \mathrm{pp}$.

MEGALOFONOU, P. 2005. Incidental catch and es- timated discards of pelagic sharks from the swordfish and tuna fisheries in the Mediterranean Sea. Fishery Bulletin, 103(4):620-634.

MEGALOFONOU, P., D. DAMALAS \& G. DE METRIO. 2009. Biological characteristics of blue shark, Prionace glauca, in the Mediterranean Sea. Journal of the Marine Biological Association of the United Kingdom, 89(6): 1233-1242.

NAKANO, H. 1994. Age, reproduction and migration of blue shark [Prionace] in the north Pacific ocean. Bulletin-National Research Institute of Far Seas Fisheries (Japan), 31:141256.

NAKANO, H., \& J. D. STEVENS. 2008. The biology and ecology of the blue shark, Prionace glauca. Sharks of the open ocean: Biology, fisheries and conservation, 140-151.

PRATT JR, H. L. 1979. Reproduction in the blue shark, Prionace glauca. Fish Bull., 77: 455470.

SIMS, D., S.L. FOWLER, F. FERRETTI \& J. STEVENS. 2016. Prionace glauca. The IUCN Red List of Threatened Species 2016: e.T39381A16553182. Downloaded on 16 August 2017.

STEVENS, J. 2009. Prionace glauca. The IUCN Red List of Threatened Species 2009: e.T39381A10222811. http://dx.doi. org/10.2305/IUCN.UK.2009-2.RLTS. T39381A10222811.en. Downloaded on 01 July 2017.

Received: 4 September 2018

Accepted: 6 March 2019 


\title{
Morfometrijske mjere mlađi psa modrulja Prionace glauca (Linnaeus, 1758) i karakteristike potencijalnih lokaliteta za njegov mrijest u obalnim vodama Crne Gore (jugoistočni Jadran)
}

\author{
Ilija ĆETKOVIĆ, Ana PEŠIĆ*, Aleksandar JOKSIMOVIĆ, Jovana TOMANIĆ i \\ Stefan RALEVIĆ
}

*Kontakt e-pošta: pesica@ucg.ac.me

\begin{abstract}
SAŽETAK
Pas modrulj pripada grupi najviše rasprostranjenih pelagičnih morskih pasa na svijetu. Obitava u pelagičnoj zoni gotovo svih umjerenih i toplih mora i oceana. Premda je jedan od najčešćih morskih pasa, često se lovi različitim ribolovnim alatima koji se koriste u pelagijalu. Ovim istraživanjem sakupljeni su prvi podaci o reprodukciji ove vrste u Crnoj Gori (Jugoistočni Jadran). Tijekom terenskih istraživanja, evidentirano je šest tek rođenih jedinki. Za tri jedinke, prikazane su detaljne morfometrijske mjere. Pored spomenutih jedinki, zabilježena je i gravidna ženka ove vrste. Svi podaci su sakupljeni u razdoblju od travnja do listopada 2017. Prema do sada objavljenoj literaturi i ovdje prikazanim podacima, moguće je da je reprodukcija ove vrste sezonska. Izvršen je i pregled lokaliteta na kojima su jedinke pronađene, kako bi se utvrdilo biraju li ih ženke kao mjesta za rađanje mladih.
\end{abstract}

Ključne riječi: Pas modrulj, Prionace glauca, Jadransko more, reprodukcija, morfometrija 
